\title{
Massive, ancient sea-ice strata and preserved physical-structural characteristics in the Ward Hunt Ice Shelf
}

\author{
MARTIN O. JEFFries \\ Geophysical Institute, University of Alaska Fairbanks, Fairbanks, AK 99775-0800, U.S.A.
}

\begin{abstract}
Two sea-ice layers, one measured as $9 \mathrm{~m}$ thick, the other at least $12 \mathrm{~m}$ thick and estimated to be $24.5 \mathrm{~m}$ thick, have been located by ice core drilling in the west Ward Hunt Ice Shelf. To examine the preservation of physical-structural characteristics over long time intervals, the crystal structure and brine volumes in the sea ice, which possibly dates back to about $3000 \mathrm{BP}$, have been studied. The structural characteristics are immediately recognizable as those of undeformed congelation sea ice accreted by Stefan growth. Brine volumes in the ancient sea ice are higher than those in modern multi-year ice at the same temperature. The preservation of brine over a time span of hundreds to thousands of years is attributed to an absence of surface meltwater to effect brine flushing and the very slow, even negligible action of gravity drainage, brine pocket migration and brine expulsion. The congelation structures indicate that sea ice can grow by the Stefan accretion mechanism to thicknesses exceeding the equilibrium thickness $(2.5-5 \mathrm{~m})$ of most undeformed multiyear ice. The observed physical-structural characteristics of the Ward Hunt sea ice strongly suggest that many of the properties attained by sea ice are permanent and not affected by slow-acting physical processes.
\end{abstract}

\section{INTRODUCTION}

Most of the ice shelves in the Arctic are located on the north coast of Ellesmere Island, NWT, Canada. These ice shelves originally grew by two primary mechanisms: (1) growth of thick sea ice, which remained landfast for many years, and (2) seaward advance of grounded glaciers. The multi-year landfast sea ice and the glacier tongues subsequently acted as basements for further ice shelf thickening by two secondary mechanisms: (1) snow accumulation and (2) bottom accretion of fresh, brackish and sea ice.

The Ward Hunt Ice Shelf, the largest of the Ellesmere ice shelves, is a sea-ice ice shelf. The original sea-ice growth of the Ward Hunt Ice Shelf has been exceptionally well dated at no later than $3000 \mathrm{BP}$ according to radiocarbon dates of driftwood from the shores of Disraeli Fiord behind the ice shelf (Crary, 1960). The ice shelf has almost certainly occupied the mouth of the fiord continuously since about $3000 \mathrm{BP}$ (Crary, 1960).

Recently, it has been shown that any sea ice that once existed in the east Ward Hunt Ice Shelf has largely been removed by ablation, although there is strong evidence for recent basal accretion of freshwater ice (Jeffries and others, 1988). On the other hand, sea ice and brackish ice layers are still found in the south and west Ward Hunt Ice Shelf (Lyons and others, 1971; Jeffries and others, 1988; Jeffries and Sackinger, 1989). The premise of this paper is that the oldest sea ice in the west Ward Hunt Ice Shelf dates back to about $3000 \mathrm{BP}$ and thus offers an unusual opportunity to examine the degree to which the physical-structural characteristics of sea ice change over extremely long time periods. Crystal structure and brine volume variations are the main characteristics considered here.

\section{METHODS}

A $76 \mathrm{~mm}$ diameter ice core (No. 83-1) was obtained with a CRREL coring auger in April/May 1983 at a location $9 \mathrm{~km}$ west of Ward Hunt Island (see Jeffries and others, 1988, Fig. 1). Coring was terminated at a depth of $31.8 \mathrm{~m}$ when core recovery became difficult due to the high liquid brine content of the ice. Once drilling was completed, the borehole was plugged to minimize air circulation and prevent infilling with drifting snow. The core was not orientated with reference to a fixed direction.

Within 68 hours after the end of coring operations, the lowermost $6.2 \mathrm{~m}$ of the borehole had filled with brine to a depth of $25.6 \mathrm{~m}$. To measure ice temperatures, a chain of thermocouples spaced $2 \mathrm{~m}$ apart was lowered to $25.6 \mathrm{~m}$ and secured at the surface before the borehole was packed with snow and ice. The first temperature readings were taken 25 days after installation and the second readings one year later. There was no significant difference between the two temperature data sets. 
Individual core specimens were wrapped in plastic bags and placed in cardboard tubes for shipment by air, first to Resolute Bay in insulated boxes, and then to Calgary in a freezer. The shipments were completed successfully, with no sample melting or mechanical damage. Ice temperatures may have reached $-10^{\circ} \mathrm{C}$ for a few hours during transportation, otherwise they were stored at $\leqslant-18^{\circ} \mathrm{C}$. During transportation and storage there may have been some brine drainage from the cores, but, as the data will show, a significant amount of brine remained in the ice.

Specific electrolytic conductivity (SEC) measured with a conductivity meter calibrated with Standard Seawater was the basis for the calculation of practical salinity according to the standard relation of UNESCO (1981). Salinity is expressed in parts per thousand (\%o). Brine volumes were calculated using the salinity and ice temperature data according to the method proposed by Cox and Weeks (1983).

After a salinity measurement had been made, the remainder of the sample was sealed in a screw-top, polyethylene bottle and kept refrigerated prior to oxygen isotope analysis with a mass spectrometer. The ratio of the heavy $\left({ }^{18} \mathrm{O}\right)$ isotope to the light $\left({ }^{16} \mathrm{O}\right)$ isotope is expressed as the fractional difference between the ratio in the sample to the ratio in the standard, V-SMOW, which has an ${ }^{18} \mathrm{O} /{ }^{16} \mathrm{O}$ ratio of $+0.07 \%$ and represents the mean oxygen isotopic composition of the World's oceans. The ${ }^{18} \mathrm{O} /{ }^{16} \mathrm{O}$ ratios are expressed as $\delta^{18} \mathrm{O}$ and measured in parts per thousand (\%o).

Selected samples were analyzed for tritium $\left({ }^{3} \mathrm{H}\right)$ activity by direct liquid scintillation counting without prior enrichment. Tritium activity was determined to an accuracy of $\pm 8 \mathrm{TU}$, where $1 \mathrm{TU}$ represents one ${ }^{3} \mathrm{H}$ atom per $10^{18}$ hydrogen atoms. The natural background of tritium in the hydrological cycle is approximately $25 \mathrm{TU}$ and above-background or anthropogenic tritium activity in ice-water relates to the atmospheric testing of hydrogen bombs, which began in 1952 with an atmospheric tritium peak occurring in 1963 (Gat, 1980).

Horizontal thin sections were cut to a thickness of $<0.5 \mathrm{~mm}$ with a microtome and photographed in crossed polarizers. As a consequence of a freezer breakdown and melting of all cores in autumn 1984, it was not possible to (1) cut vertical sections to document structural-stratigraphic variations of individual sea ice layers, (2) measure $c$-axis orientations and (3) make detailed measurements of crystal size and sub-structure, e.g. brine layer spacing.

\section{STRATIGRAPHY AND AGE}

The salinity and $\delta^{18} \mathrm{O}$ profiles for core 83-1 are shown in Figure 1. It is evident that the core penetrated four distinct layers, one of which (4) has been further divided into two. The SEC, salinity and $\delta^{18} \mathrm{O}$ data are summarized in Tables 1 and 2.

Stratum $1(0-10 \mathrm{~m})$, with negligible salinities and very negative $\delta^{18} \mathrm{O}$ values, is superimposed ice formed by melting and refreezing of snowpacks at the ice shelf surface. Stratum $3(19-20 \mathrm{~m})$ also has very negative $\delta^{18} \mathrm{O}$ values, but with only one exception they are all more positive than those of Stratum 1 (Table 2). The level of dissolved impurities in Stratum 3 is two orders of

Table 1. Summary of SEC and salinity data for individual layers identified in core 83-1, west Ward Hunt Ice Shelf. Figures in brackets denote the number of samples analyzed. The SEC values of Stratum 1 are too low to be expressed meaningfully as salinity values, hence the presentation of SEC values.

\begin{tabular}{|c|c|c|c|c|c|c|}
\hline & \multicolumn{3}{|c|}{$\begin{array}{l}\text { SALINITY } \\
(\%)^{\circ}\end{array}$} & \multicolumn{3}{|c|}{$\begin{array}{c}\mathrm{SEC} \\
\left(\mu \mathrm{S} \mathrm{cm}^{-1}\right)\end{array}$} \\
\hline & MAX. & MIN. & MEAN & MAX. & MIN. & MEAN \\
\hline $\begin{array}{l}\text { STRATUM } 1 \\
0-10 \mathrm{~m}\end{array}$ & - & - & - & 38.1 & 1.8 & $8.0 \pm \frac{5.8}{(52)}$ \\
\hline $\begin{array}{l}\text { STRATUM } 2 \\
10-19 \mathrm{~m}\end{array}$ & 3.59 & 0.28 & $1.99 \pm 0.6$ & 4603 & 537 & $2743 \pm \frac{1011}{(58)}$ \\
\hline $\begin{array}{l}\text { STRATUM } 3 \\
19-20 \mathrm{~m}\end{array}$ & 0.39 & 0.04 & $0.17 \pm 0.1$ & 615 & 63 & $254 \pm \frac{173}{(6)}$ \\
\hline $\begin{array}{l}\text { STRATUM 4A } \\
20-25.6 \mathrm{~m}\end{array}$ & 3.89 & 1.20 & $2.28 \pm 0.6$ & 5471 & 1809 & $3268 \pm 854$ \\
\hline $\begin{array}{l}\text { STRATUM 4B } \\
25.6-31.8 \mathrm{~m}\end{array}$ & 15.34 & 2.04 & $7.43 \pm 4.1$ & 19498 & 2924 & $9839 \pm 5110$ \\
\hline
\end{tabular}


Table 2. Summary of $\delta^{18} \mathrm{O}$ data for individual layers identified in core 83-1, west Ward Hunt Ice Shelf. Figures in brackets denote the number of samples analyzed.

$\delta^{18} \mathrm{O}$

(\%)

MAX. MIN. MEAN

$\begin{array}{lccc}\text { STRATUM 1 } & -26.2 & -35.1 & -30.5 \pm 3.6 \\ 0-10 \mathrm{~m} & & (52) \\ & & & -1.8 \pm 1.9 \\ \text { STRATUM 2 } & -0.5 & -10.5 & (55) \\ 10-19 \mathrm{~m} & & & -24.2 \pm 3.4 \\ & & -17.5 & (6) \\ \text { STRATUM 3 } & -26.6 & & -1.7 \pm 1.9 \\ \begin{array}{l}\text { 19-20m } \\ \text { STRATUM 4A }\end{array} & 0.0 & -11.6 & (32) \\ \begin{array}{l}\text { 20-25.6m } \\ \text { STRATUM 4B }\end{array} & +0.8 & -1.8 & -0.6 \pm 0.8 \\ \text { 25.6-31.8m } & & & (16)\end{array}$

magnitude greater than in Stratum 1 (Table 1). Stratum 3 is fresh-water ice or brackish ice accreted from low salinity water. Strata 1 and 3 are not considered further in this paper.

Stratum $2(10-19 \mathrm{~m})$ and Stratum $4(20 \mathrm{~m}$ to at least $31.8 \mathrm{~m})$, each with high salinities and $\delta^{18} \mathrm{O}$ values close to V-SMOW, are sea ice with a two to three orders of magnitude greater level of dissolved impurities than Strata 1 and 3. It is noted that the highest ice salinities occur below $25.6 \mathrm{~m}$ in Stratum 4, the level the brine reached in the borehole (referred to as the level of brine upwelling). Accordingly, Stratum 4 is divided into Stratum 4A (20$25.6 \mathrm{~m})$ and Stratum $4 \mathrm{~B}(>25.6 \mathrm{~m})$. Stratum $4 \mathrm{~B}$ was the only layer in core $83-1$ to have above-background or anthropogenic tritium levels (Fig. 1).

The disposition of superimposed ice (Stratum 1) on sea ice (Stratum 2) in core 83-1 (Fig. 1) strongly resembles the model of sea-ice ice shelf growth, which began about $3000 \mathrm{BP}$. It is quite possible that Stratum 2 represents some of the original multi-year landfast sea-ice basement of the early Ward Hunt Ice Shelf. A major warm interval is believed to have ended about $1600 \mathrm{BP}$ when surface build-up recommenced after a period of negative surface mass balance (Crary, 1960; Lyons and others, 1972). Stratum 3 is believed to have accreted at some time during that warm climatic interval from low salinity water flowing below the western ice shelf (Jeffries and others, 1988). Basal sea-ice accretion, i.e. Stratum 4, resumed after the climate deteriorated at about $1600 \mathrm{BP}$.

Basal ice accretion may not have been continuous, since there may have been periods of bottom melting. Consequently, there may be unconformities in core 83-1; it might have been possible to identify unconformities
Jeffries: Preserved physical-structural characteristics of sea ice OXYGEN-18 (o/OO)

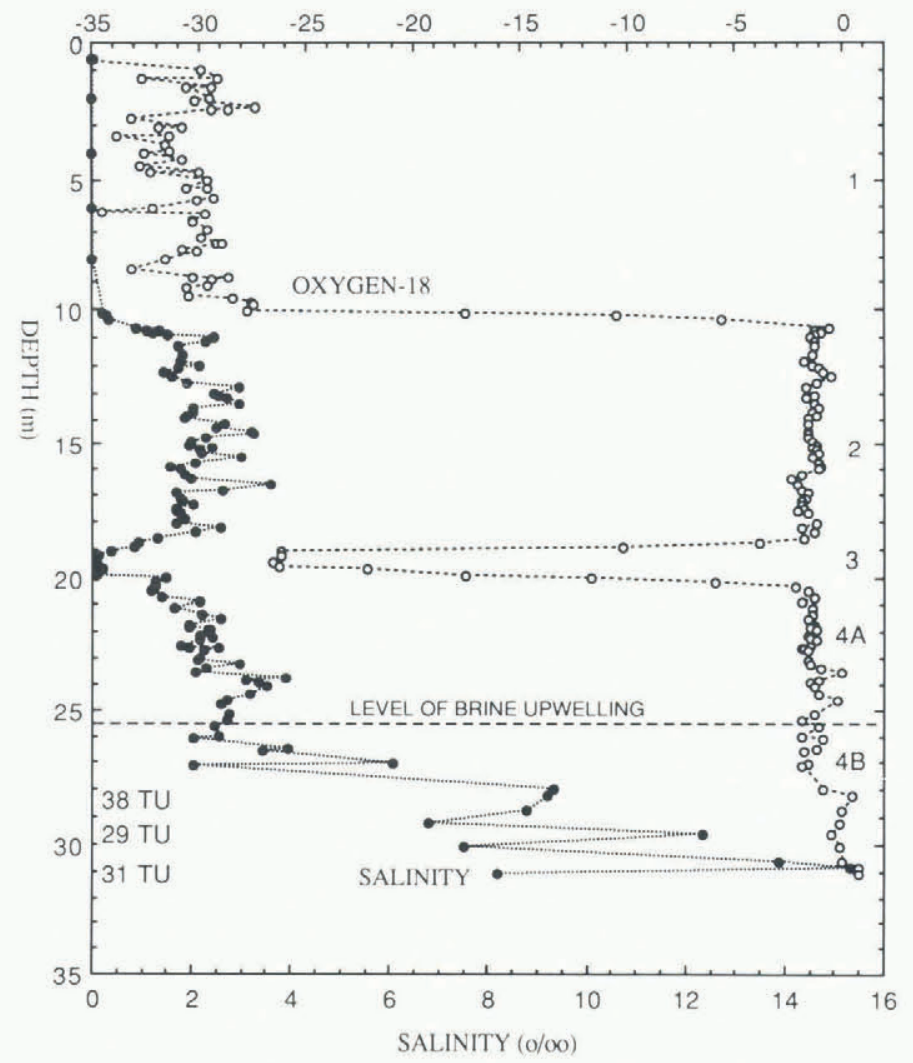

Fig. 1. Salinity (solid circles) and $\delta^{18} \mathrm{O}$ (open circles) profiles for ice core 83-1, west Ward Hunt Ice Shelf. Anthropogenic tritium values are shown at the lower left side at the depths they occurred. A four layer stratigraphy is apparent and the number of each Stratum is shown at the right side.

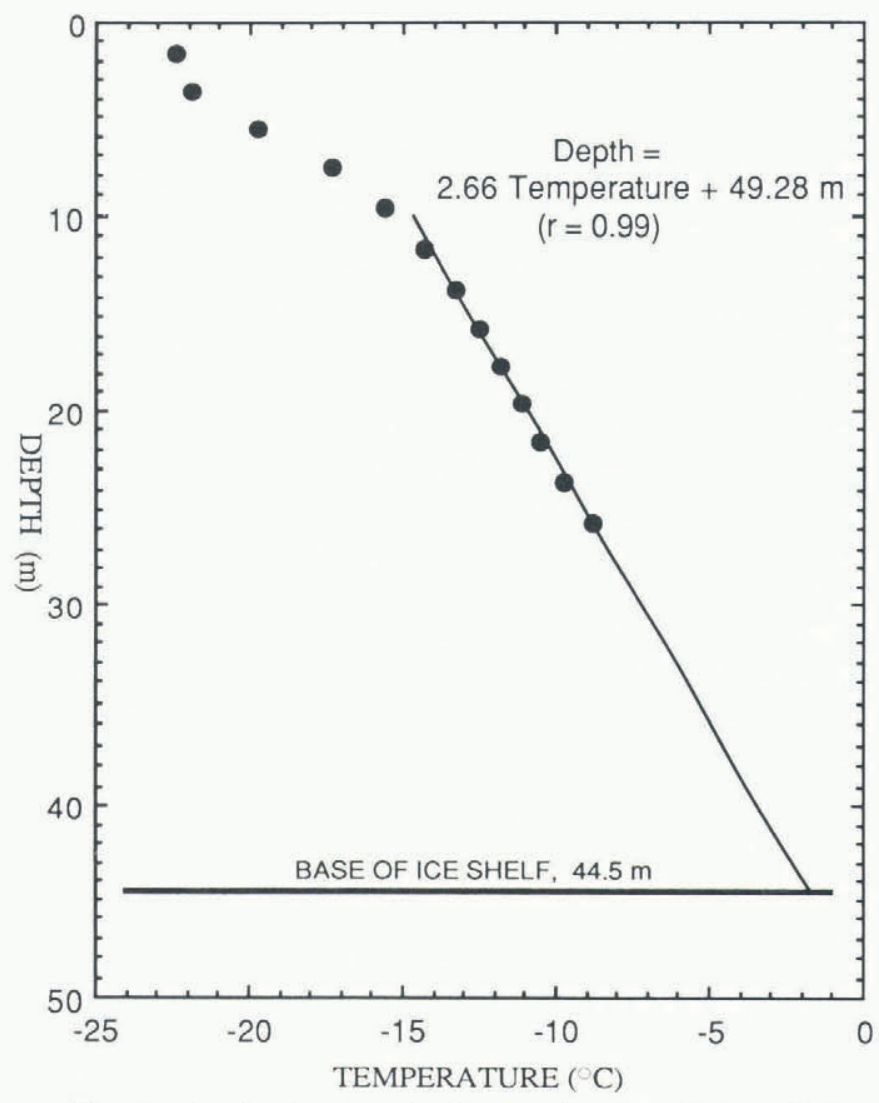

Fig. 2. Ice temperature profile at the site of core 83-1 measured on 31 May 1983, 25 days after the thermocouples were installed in the borehole. Data points are at $2 \mathrm{~m}$ intervals. 
according to crystal size variations, but they cannot be identified with the available salinity, $\delta^{18} \mathrm{O}$ and physicalstructural property data. Nevertheless, the observed stratigraphy below $10 \mathrm{~m}$ probably represents a simple age-depth relation, with the ice becoming younger as depth increases. The exact age of the ice at a given depth cannot be determined, but it is entirely plausible that ice in Stratum 1 and Stratum 2 is as much as 3000 years old, Stratum 3 is no younger than 1600 years and Stratum 4 is no older than 1600 years.

\section{TEMPERATURE AND THICKNESS}

The ice temperature profile at the site of core $83-1$ is shown in Figure 2. From the surface to $10 \mathrm{~m}$, the profile is curvilinear, as this is the zone of seasonal temperature change, with a measured minimum of $-22.4^{\circ} \mathrm{C}$ and a $10 \mathrm{~m}$ temperature of $-14.7^{\circ} \mathrm{C}$. Below $10 \mathrm{~m}$, the profile is linear and at $25.6 \mathrm{~m}$, the lowest thermocouple located at the level of brine upwelling, the temperature is $-8.8^{\circ} \mathrm{C}$. Jeffries and others (1988) have previously inferred that sea water entering Disraeli Fiord flows eastward beneath the west Ward Hunt Ice Shelf. Assuming a minimum possible seawater temperature of $-1.8^{\circ} \mathrm{C}$, then, according to the depth-temperature relationship (Fig. 2), the total ice shelf thickness is estimated conservatively to be $44.5 \mathrm{~m}$. This is in good agreement with previous thickness measurements and estimates. If Stratum 4 extends beyond $31.8 \mathrm{~m}$ to the base of the ice shelf, it must be $24.5 \mathrm{~m}$ thick.

\section{PHYSICAL-STRUCTURAL CHARACTERISTICS}

\section{Crystal structure}

Two sea ice specimens from Stratum 2 are illustrated in Figure 3. Long, narrow, interlocking crystals are aligned parallel to each other. Within individual crystals, there are many discrete, regularly-spaced inclusions aligned with their long axes parallel to those of the crystals. The inclusions are believed to be brine cells that originally formed at the ice platelet boundaries, but which are now no longer interconnected. A similar sub-structure was observed in Stratum 4A. The sea ice in Stratum 4B (Figs $4 \mathrm{a}$ and $4 \mathrm{~b}$ ) strongly resembles that in Stratum 2 (Figs $3 \mathrm{a}$ and $3 \mathrm{~b}$ ) and Stratum $4 \mathrm{~A}$. In Stratum 4B, however, a cellular sub-structure of interconnecting, regularly-spaced brine cells and ice platelets is more recognizable than in Strata 2 and 4A (Fig. 4a). One of the specimens (Fig. 4b) has somewhat larger crystals, but they also appear to be aligned.

The structures observed in Strata 2 and 4 are typical of congelation sea ice that has accreted by Stefan growth (Weeks and Ackley, 1986). In some cases ice growth apparently has been very slow at times; hence the large crystals in Figure $4 \mathrm{~b}$. The crystal alignment suggests there may have been water current control of crystal growth (e.g. Weeks and Gow, 1978); but, since no c-axis orientation measurements were made, it is not known for certain whether there is a preferred crystal orientation in the Ward Hunt sea ice. No structural evidence was found for mechanical deformation of the ice, e.g. granular
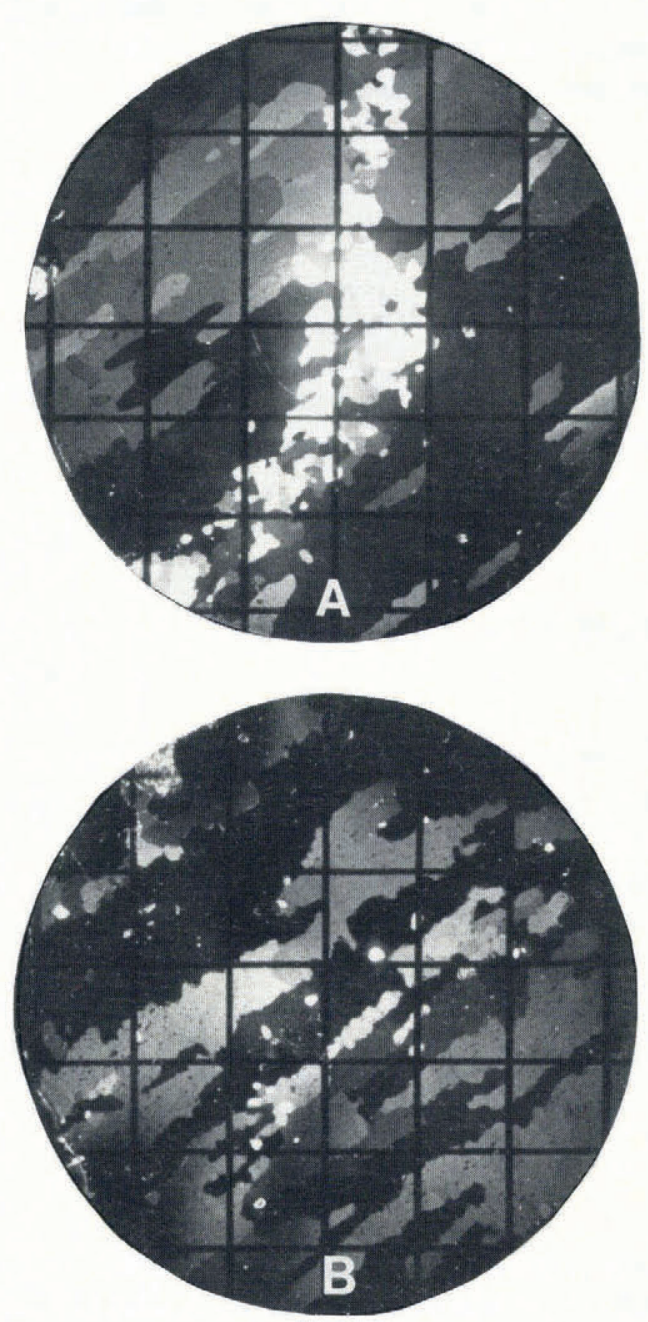

Fig. 3. Horizontal thin sections of sea ice from $16.93 \mathrm{~m}(A)$ and $18.10 \mathrm{~m}(B)$ in Stratum 2, core $83-1$ (10 $\mathrm{mm}$ grid for scale). The bright, curvilinear feature across the width of one of the specimens $(A)$ is interpreted as the trace of a former brine drainage channel.

textures, brecciated structures and healed fractures found in consolidated ice ridges (Cox and others, 1985).

Although the macro sea-ice structures are readily identifiable, the sub-structures in Strata 2 and $4 \mathrm{~A}$ in particular are not as well developed as they would be in recently grown sea ice. It is reasonable to assume that all the sea ice in core 83-1 originally had a well developed sub-structure of brine cells and ice platelets, but that it has since deteriorated. The modification of the cellular substructure of brine cells and ice platelets has been observed in the upper layers of multi-year floes and is attributed to retexturing influenced by elevated summer temperatures and increased solar radiation (Tucker and others, 1987). This cannot explain adequately the breakdown of the substructure in Strata 2 and $4 \mathrm{~A}$, since the ice has probably never been exposed at the surface. The retexturing evident in these layers may simply be a consequence of their great age, and, since the brine cells in these layers are now no longer interconnected, the ice is probably quite impermeable. In Stratum 4B, where the characteristic sea-ice cellular sub-structure is still recognizable, the ice may be more permeable. 

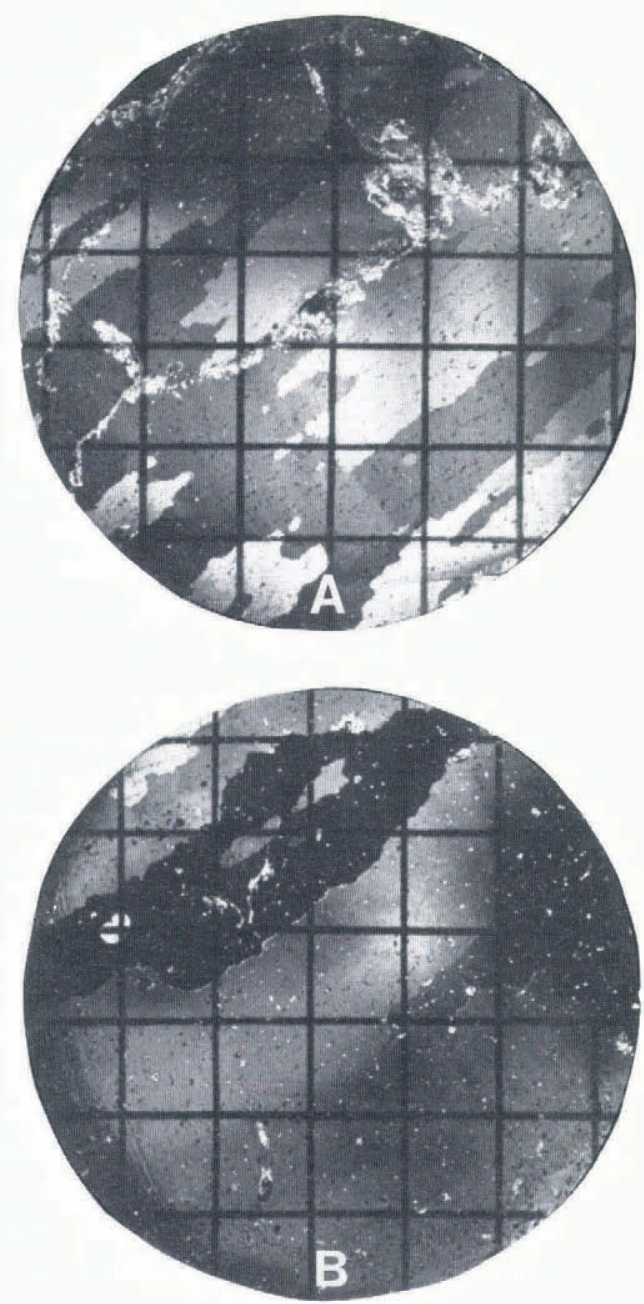

Fig. 4. Horizontal thin sections of sea ice from $29.23 \mathrm{~m}(A)$ and $31.10 \mathrm{~m}(B)$ in Stratum $4 B$, core $83-1$ (10 mm grid for scale). A brine drainage channel is apparent in specimen $A$.

\section{Brine volumes and brine movement}

In core $83-1$, Stratum 4B below $25.6 \mathrm{~m}$ has been found to be congelation sea ice with high salinities and anthropogenic tritium levels. The tritium is not an indication of any fresh-water influence, because the associated $\delta^{18} \mathrm{O}$ values are actually closer to V-SMOW than those in Strata 2 and $4 \mathrm{~A}$. The high tritium values may indicate that the ice has accreted only since 1952, when anthropogenic tritium was first introduced. Growth rates due to pure conduction through the ice shelf have not been calculated, but it seems unlikely that almost $20 \mathrm{~m}$ of congelation sea ice would accrete in 30 years or less; consequently, this explanation can probably be discounted.

An alternative explanation for the high tritium values and high ice salinites in Stratum $4 \mathrm{~B}$ is that the brine is modern and younger than the ice, and originates from the sea water flowing below the ice shelf. The mechanisms by which an exchange of young, dense brine within layers of older, less dense ice may occur are unclear, but for modern sea water with high tritium values and oceanic $\delta^{18} \mathrm{O}$ values to be found almost $20 \mathrm{~m}$ above the base of the ice shelf also suggests that Stratum $4 \mathrm{~B}$ is permeable, unlike Strata 2 and 4A. From this phenomenon it may be inferred that the sea ice extends all the way to the base of the ice shelf at $44.5 \mathrm{~m}$; hence, the earlier suggestion that Stratum 4 is $24.5 \mathrm{~m}$ thick.

The high ice salinities resulting from the apparent upward brine movement in the lower half of the ice shelf contrast somewhat with the salinity of ice in Strata 2 and 4A. Nevertheless, the salinity values in those layers compare well with modern multi-year ice salinities (e.g. Schwarzacher, 1959; Cox and Weeks, 1974). For a better perspective on the salinity of the ice-shelf sea ice and multi-year ice at the same temperature, a comparison of brine volume variations is presented in Figure 5. The average brine volumes of Strata 2 and $4 \mathrm{~A}$ are $9.9 \%$ (range $4.2-16.7$ ) and $12.8 \%$ (range 6.6-21.8), respectively. In contrast, the multi-year ice brine volumes range from 1.5 to $15.3 \%$ with a mean value of $5.4 \%$. The brine volumes in core 83-1 are an order of magnitude greater than those in multi-year ice at the same temperature, despite a two to three orders of magnitude difference in age.

Brine drainage from sea ice occurs by flushing, gravity drainage, brine pocket migration and brine expulsion (Weeks and Ackley, 1986). If there had been meltwater infiltration of the sea ice in core $83-1$, the $\delta^{18} \mathrm{O}$ values would be somewhat more negative, but, as they remain very close to V-SMOW (Table 2), meltwater infiltration can be discounted as a means of brine removal. The lack of infiltrating surface meltwater and associated seasonal ice temperature variations in Strata 2 and $4 \mathrm{~A}$ implies that the temperature gradient has probably been maintained

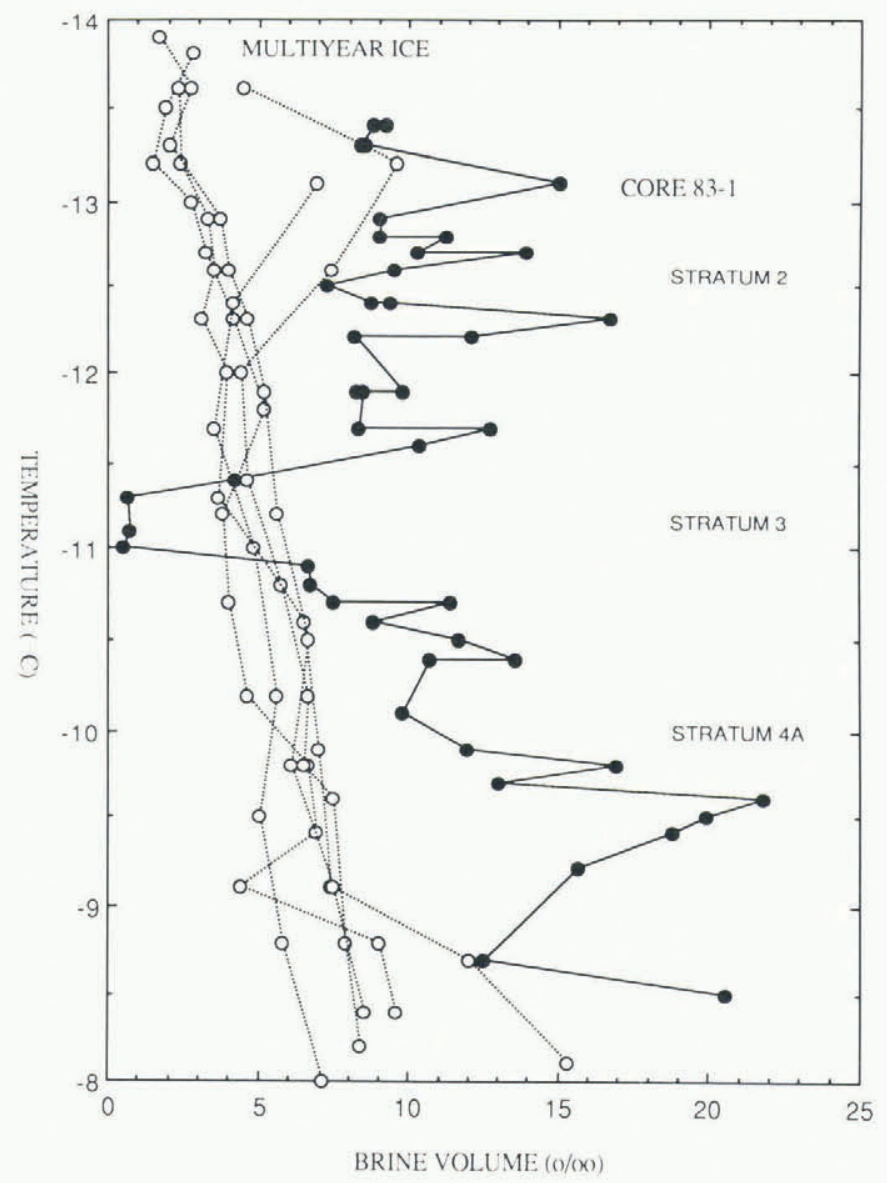

Fig. 5. Temperature dependence of brine volumes in core 831, Strata 2, 3 and 4 (solid circles), and in five Arctic Ocean multi-year ice cores obtained in April 1986, north of Greenland (open circles; courtesy of W.F. Weeks). 
nearly constant and seasonal temperature fluctuations have been minimized. Consequently, brine expulsion and brine pocket migration, which require strong temperature gradients to be effective, have also probably been minimized. Possible traces of former brine drainage channels have been found in the ice (Figs $3 a$ and $4 a$ ) and indicate that this process contributed to brine removal at one time. The data, however, indicate that its effect was subsequently reduced, perhaps due to the breakdown of the cellular sub-structure and the disconnection of the brine cells.

An additional factor in the retention of brine may be temperature-related phase changes and variations in brine chemistry. It is recalled that the maximum measured ice temperature, at the level of brine upwelling, is $-8.8^{\circ} \mathrm{C}$. This is close to the initial crystallization temperature $\left(-8.2^{\circ} \mathrm{C}\right)$ of mirabilite $\left(\mathrm{Na}_{2} \mathrm{SO}_{4} \cdot 10 \mathrm{H}_{2} \mathrm{O}\right)$ (Weeks and Ackley, 1986). The effects of solid salts on sea-ice chemistry and physical-structural properties are poorly understood, but it is possible that there is some combined thermo-chemical control on (1) downward brine movement in Strata 2 and $4 \mathrm{a}$ (in addition to the factors noted in the previous paragraph) and (2) the maximum level attainable by upward-moving brine in Stratum 4B with solid salt crystallization in brine cells reducing permeability.

\section{DISGUSSION}

According to the ice core stratigraphy and physicalstructural characteristics, at least part of the west Ward Hunt Ice Shelf comprises four distinct layers for a total ice thickness of $44.5 \mathrm{~m}$. Two of the layers are congelation sea ice, $9 \mathrm{~m}$ (Stratum 2) and $24.5 \mathrm{~m}$ (Stratum 4) thick. There is no evidence that they have attained these thicknesses by mechanical deformation. Indeed, very slow creep deformation could actually have caused a slight thinning over time. To all intents and purposes, the sea ice may be considered as undeformed congelation sea ice, which has undoubtedly accreted by Stefan growth. Based on previous examinations of the structural characteristics of sea ice in ice islands, those found in the west Ward Hunt Ice Shelf are not entirely unexpected. Smith (1964) found strong crystal orientations in congelation ice that comprised about half the ice island ARLIS-II. Likewise, Cherepanov (1966) described strongly aligned crystals in the 10 to $12 \mathrm{~m}$ thick sea ice that made up the entire $80 \mathrm{~km}^{2}$ area of ice island SP-6. The most likely sources for both ice islands were the Ellesmere ice shelves.

The thickness of Stratum $4(24.5 \mathrm{~m})$ exceeds the thickness of SP-6, and the sea ice layers observed in the south Ward Hunt Ice Shelf (Lyons and others, 1971). Smith (1964) found some $20 \mathrm{~m}$ thick sea ice in parts of ARLIS-II, but folds in the ice indicated that this thickness had been attained by mechanical deformation. The characteristics of undeformed sea ice exceeding 10-12 m thickness have not previously been observed and described in the Arctic. Although the congelation sea ice in ice islands ARLIS-II and SP-6 was undoutedly quite old, it is unlikely that congelation sea ice of the great age and thickness found in west Ward Hunt Ice Shelf has previously been located and studied elsewhere in the Arctic.
Multi-year sea ice that has grown entirely by the Stefan growth mechanism in the Arctic Ocean commonly has an equilibrium thickness of 2.5 to $5 \mathrm{~m}$ (Weeks and Ackley, 1986). The congelation sea ice in the Ward Hunt Ice Shelf indicates that under some circumstances sea ice can attain thicknesses exceeding 10 to $12 \mathrm{~m}$ by the same mechanism. The age, thickness and properties of the Ward Hunt sea ice lend support to numerical modelling experiments of thick sea-ice growth, where $>20 \mathrm{~m}$ of sea ice has been "grown" over a period of 200 years or more (Walker and Wadhams, 1979).

Although Stratum 4 is unusually thick for Arctic sea ice, there are Antarctic precedents for such thick sea-ice growth and its occurrence at the base of an ice shelf. Although they are quite possibly congealed frazil ice, massive layers of sea ice have been found at the base of the Amery Ice Shelf (Morgan, 1972) and the central Ronne Ice Shelf (Engelhardt and Determann, 1987). More germane to the Ward Hunt sea ice is the lowermost $6 \mathrm{~m}$ of ice at site J-9 on the Ross Ice Shelf ( 410 to $416 \mathrm{~m}$ below the ice surface), which had a salinity of $2-4 \%$ and typical congelation sea-ice structures (Zotikov and others, 1980).

An unexpected result of this study, in view of the age of the ice, was the discovery of high ice salinity values and brine volumes. Some of these are in a layer where high tritium values suggest that the brine is much younger than the ice and is being exchanged with the sea water flowing below the ice shelf. This circulation of brine apparently also caused an upwelling of brine in the borehole after drilling ceased. This was not an isolated case. Crary (1958) reported a similar phenomenon in 1954 in a borehole located about $4 \mathrm{~km}$ west of Ward Hunt Island, i.e. about $5 \mathrm{~km}$ east of core $83-1$. In that case, brine infiltration began at a depth of $24.5 \mathrm{~m}$ and a few days later the brine level was at about $23.5 \mathrm{~m}$. At this time, no mechanism can be offered to explain this phenomenon, but it merits further study as it has implications for the physical processes and their effects on the physicalstructural properties of much younger multi-year ice.

In the older sea ice unaffected by brine exchange, the brine volumes exceed those of modern multi-year ice. Under most circumstances, the most effective means of brine removal from sea ice is brine flushing by percolation of surface meltwater, with brine expulsion, brine pocket migration and gravity drainage playing a secondary role (Weeks and Ackley, 1986). Flushing has been ruled out entirely in this study. Thus, the data suggest that a combination of brine expulsion, brine pocket migration and gravity drainage have not achieved the same degree of desalination over a period of hundreds of years that may be achieved during a single summer warming in younger pack ice floes. Those secondary brine drainage processes apparently have acted at very slow, even negligible rates in this unusual multi-year ice.

\section{CONCLUSION}

Massive sea-ice strata, as much as $24.5 \mathrm{~m}$ thick and ranging in age from possibly as much as 3000 years old to modern, are found in the west Ward Hunt Ice Shelf. The characteristics of congelation sea ice of this age and thickness have not previously been observed and described 
in the Arctic. Other than some breakdown in the substructure of brine layers and ice platelets, all the ice has well preserved structural characteristics immediately recognizable as those of congelation sea ice. The congelation ice structures in this thick sea ice indicate that, under some circumstances, sea ice can grow by the Stefan accretion mechanism to thicknesses far exceeding the 2.5 to $5 \mathrm{~m}$ equilibrium thickness of undeformed multiyear pack ice. In spite of its age, the ice has retained a significant amount of brine, with brine volumes exceeding those of modern multi-year ice at the same temperature. The preservation of the physical-structural characteristics can be attributed primarily to the absence of meltwater infiltration from the surface to effect brine flushing and retexturing. In the absence of brine flushing by infiltrating meltwater, the observed physical-structural characteristics of the Ward Hunt sea ice suggest strongly that many of the properties attained by sea ice are permanent and not affected by other slow-acting physical processes. The west Ward Hunt Ice Shelf contains an important geophysical sample repository, very old sea ice, which offers the opportunity to improve the knowledge and understanding of sea-ice physical-structural properties and processes, and which may also contain useful proxy records of oceanographic variability, e.g. biota, water properties.

\section{ACKNOWLEDGEMENTS}

Fieldwork and laboratory analysis were undertaken when I was a graduate student at the University of Calgary. Logistical support was provided by the Polar Continental Shelf Project. Financial support was provided by the Arctic Institute of North America, the Canadian Defence Research Establishment Pacific (Arctic Acoustics Section), Gulf Canada, Dome Petroleum and Petro-Canada. Ice core 83-1 was obtained with the assistance of $\mathrm{Mr} \mathrm{H}$. Serson and Dr G. Holdsworth. Oxygen isotope analysis was done in the Stable Isotope Laboratory, Unversity of Calgary, supervised by Dr R. Krouse. Tritium measurements were made in the Isotope Laboratory, University of Waterloo, then supervised by Dr P. Fritz. This paper was written at the Geophysical Institute, University of Alaska Fairbanks, where I have enjoyed the strong support and encouragement of the Director, Dr A.-I. Akasofu and benefitted from many discussions with Dr W.F. Weeks and Dr W.M. Sackinger. Willy Weeks also made available the multiyear ice brine volume data and a Macintosh computer version of the Cox and Weeks (1983) brine volume algorithms.

\section{REFERENCES}

Cherepanov, N.V. 1964. Struktura morskikh l'dov bol'shoy tolshchiny [Structure of sea ice of great thickness]. In Arkt. Antarkt. Nauchno-Issled. Inst. 267, 13-18. (English translation in Defence Research Board Canada. Directorate of Scientific Information Services. Translation T 448 R, 1966.)

Cox, G.F.N. and W.F. Weeks. 1974. Salinity variations in sea ice. J. Glaciol., 13(67), 109-120.
Cox, G.F.N. and W.F. Weeks. 1983. Equations for determining the gas and brine volumes in sea-ice samples. J. Glaciol., 29 (102), 306-316.

Cox, G.F.N., and 6 others. 1985. Mechanical properties of multi-year sea ice. Phase II: Test results. CRREL Rep. 85-16.

Crary, A.P. 1958. Arctic ice island and ice shelf studies. Part I. Arctic, 11(1), 3-42.

Crary, A.P. 1960. Arctic ice island and ice shelf studies. Part II. Arctic, 13(1), 32-50.

Engelhardt, H. and J. Determann. 1987. Borehole evidence for a thick layer of basal ice in the central Ronne Ice Shelf. Nature, 327(6120), 318-319.

Gat, J.R. 1980. The isotopes of hydrogen and oxygen in precipitation. In Fritz, P. and J.C. Fontes, eds. Handbook of environmental isotope geochemistry. Vol. I. The terrestrial environment, A. Amsterdam, Elsevier Scientific Publishing Co., 21-47.

Jeffries, M.O. and W.M. Sackinger. 1989. Some measurements and observations of very old brackish ice and sea ice, Ward Hunt Ice Shelf, N.W.T. Atmosphere-Ocean, 27(3), 553-564.

Jeffries, M.O., W.M. Sackinger, H.R. Krouse, and H.V. Serson. 1988. Water circulation and ice accretion beneath Ward Hunt Ice Shelf (northern Ellesmere Island, Canada) deduced from salinity and isotope analysis of ice cores. Ann Glaciol., 10, 68-72.

Lyons, J.B., S.M. Savin, and A.J. Tamburi. 1971. Basement ice, Ward Hunt Ice Shelf, Ellesmere Island, Canada. J. Glaciol., 10(58), 93-100.

Lyons, J.B., R.H. Ragle, and A.J. Tamburi. 1972. Growth and grounding of the Ellesmere Island ice rises. $J$. Glaciol., 11(61), 43-52.

Morgan, V.I. 1972. Oxygen isotope evidence for bottom freezing, Amery Ice Shelf. Nature, 238(5364), 393-394.

Schwarzacher, W. 1959. Pack-ice studies in the Arctic Ocean. J. Geophys. Res., 64(12), 2357-2367.

Smith, D.D. 1964. Ice lithologies and structure of ice island ARLIS II. J. Glaciol., 5(37), 17-38.

Tucker, W.B., III, A.J. Gow, and W.F. Weeks. 1987. Physical properties of summer sea ice in the Fram Strait. J. Geophys. Res., 92(C7), 6787-6803.

UNESCO. 1981. International oceanographic tables. Vol. 3. UNESCO Tech. Pap. Mar. Sci. 39.

Walker, E.R. and P. Wadhams. 1979. Thick sea-ice floes. Arctic, 32(2), 140-147.

Weeks, W.F. and S.F. Ackley. 1986. The growth, structure, and properties of sea ice. In Untersteiner, N., ed. Geophysics of sea ice. New York and London, Plenum Press, 9-164.

Weeks, W.F. and A.J. Gow. 1978. Preferred crystal orientation in the fast ice along the margins of the Arctic Ocean. J. Geophys. Res., 83(C10), 5105-5121.

Zotikov, I.A., V.S. Zagorodnov, and J. Raikovsky. 1980. Core drilling through the Ross Ice Shelf (Antarctica) confirmed basal freezing. Science, 207(4438), 14631465 .

The accuracy of references in the text and in this list is the responsibility of the author, to whom queries should be addressed. 